\title{
Mineral associations and compositional evolution of Monastery kimberlite megacrysts.
}

\author{
Gurney, J.J. ${ }^{1}$, Moore, R.O. ${ }^{2}$, Bell, D.R. ${ }^{1}$
}

1 Department of Geological Sciences, University of Cape Town, Rondebosch 7700, South Africa

2 \#3-1419 Pendrewl Street, Vancouver V6G 1S3, Canada

Introduction. The Monastery kimberlite in the Eastern Free State of South Africa contains an exceptionally well represented suite of inclusions of the Cr-poor megacryst (discrete nodule) association, making it an ideal location to study in detail the processes responsible for megacryst petrogenesis (Gurney et al., 1979). A renewed phase of prospecting beginning in 1982 resulted in exposure of deeper kimberlite levels and recovery of zircons alongside diamond in the Sortex plant, allowed for a reexamination of the suite, with an emphasis on some of the less common megacryst associations. A large number of megacrysts from in-situ kimberlite occurrences, oversize concentrate tailings, and Sortex production, including some 2,200 zirconbearing samples were examined. This study reports on these observations and on chemical analyses by electron-, ion-, and proton-microprobe which delineate the compositional evolution of a wide range of Monastery megacrysts and define at least two distinct series of megacryst associations.

Megacryst occurrences. The relative mineral abundances determined in this study contrast somewhat with previous observations (Gurney et al., 1979). They are (in decreasing order): ilmenite, olivine, diopside-ilmenite, garnet, phlogopite, diopside, enstatite, enstatite-ilmenite, garnet - ilmenite, diopside-enstatite, followed by occasional (rare) occurences of the following: garnet - diopside, olivine-ilmenite, olivine-garnet, olivine-enstatite, olivine-diopside, phlogopite-ilmenite, zircon, zirconilmenite, zircon-olivine, zircon-phlogopite and occasional 3-phase intergrowths of some of the above. One four-phase olivine-zircon-phlogopite-ilmenite intergrowth has been found as well as two unusual four-phase peridotites comprising olivineenstatite-diopside-garnet with composition similar to the most primitive megacrysts. The texture of these garnet lherzolite xenoliths is coarse-equant, though grain size is from 0.5 to $5 \mathrm{~mm}$; relatively fine-grained for undeformed peridotite xenoliths. Of the 2,200 zircon-bearing samples, $88 \%$ are monomineralic, the remainder comprising 248 (11\%) zircon-ilmenite, 16 olivine-bearing intergrowths and 3 phlogopite-bearing samples. Average zircon grain size is $10 \mathrm{~mm}$. A new population of calcic clinopyroxene megacrysts has been identified on the basis of major element composition (see below). These megacrysts are not readily distinguishable from the common subcalcic diopsides in hand specimen and occur as discrete megacrysts or intergrown with ilmenite and in one case, phlogopite. Previous workers have implicated carbonate crystallization in megacryst evolution. No carbonate megacrysts are observed; spherical or tubular inclusions of calcite \pm serpentine \pm phlogopite in ilmenite megacrysts may represent trapped carbonatitic liquids.

Megacryst compositions. Two distinct populations of each of the minerals olivine, ilmenite and clinopyroxene are recognized on the basis of chemical composition. 
Ilmenite consists of a high $\mathrm{Cr}$, high $\mathrm{Nb}$ (and low $\mathrm{Zr} / \mathrm{Nb}$ ) population (groups 2 and 3 of Moore et al., 1992) which may be associated with zircon, phlogopite, Fe-rich olivine or calcic clinopyroxene and a low- $\mathrm{Cr}$, low $\mathrm{Nb}$, high $\mathrm{Zr} / \mathrm{Nb}$ group which is the compositional type found intergrown with subcalcic clinopyroxene, garnet and enstatite of the "main silicate trend (MST)" (group 1 of Moore et al 1992.). 166 new olivine analyses confirm the division of olivine into high-Fe, low-Ni and low-Fe, high-Ni groups as recognized by Gurney et al (1979). These groups are also distinct in their trace element content and the speciation of their trace structural $\mathrm{OH}$. Only the high-Fe group coexists with ilmenite, phlogopite or zircon, while the low-Fe group coexists with MST pyroxenes and garnet only. Phlogopites are similar in composition to those from MARID xenoliths, but show far better defined compositional trends. The separate population of calcic clinopyroxene mentioned above is characterized by $\mathrm{Ca} \#(=100 \mathrm{Ca} /[\mathrm{Ca}+\mathrm{Mg}])>45$, low $\mathrm{Al}$, elevated $\mathrm{Cr}$ and high incompatible trace element contents relative to the MST subcalcic clinopyroxenes.

For the MST minerals, most elements show a very regular variation in composition with Mg\#. Subtle indications of a lack of continuum among MST pyroxene compositions are revealed by the new data, with ilmenite free and ilmenite-bearing populations separated by narrow compositional gaps. For certain trace elements (e.g., $\mathrm{Ce}$ in garnet), the compositional evolution is opposite to that predicted for a fractionating magma and points to the strong effect of systematically varying mineral - liquid partitioning in producing observed trends. Such observations imply that great care should be exercised in the use of mineral trace element concentrations (e.g., $\mathrm{Nb}$ in ilmenite) to predict quantitatively the degree of fractionation.

Discussion of petrogenetic associations. At least two associations of megacrysts are distinguished when chemical and mineral coexistence observations are combined. These are:

(1). The "main silicate trend", comprising subcalcic clinopyroxene, garnet, enstatite, low-Fe high $\mathrm{Ni}$ olivine, the latter replaced at lower $\mathrm{Mg \#}$ by low $\mathrm{Cr}$, low $\mathrm{Nb}$, high $\mathrm{Zr} / \mathrm{Nb}$ ilmenite.

(2) The "metasomatic" trend, comprising phlogopite, calcic clinopyroxene, Cr-, $\mathrm{Nb}$-rich ilmenite, high $\mathrm{Fe}$ low $\mathrm{Ni}$ olivine and zircon. This consists of a more magnesian group of megacrysts (phl - cpx - ilm), separated from the evolved group (ilm - phl - FeOliv - zir) by a compositional gap in which little ilmenite appears to crystallize. This "metasomatic" megacryst association has been so named because the mineral associations and compositions (major and trace elements) bear resemblance (but are not identical) to those of the MARID - glimmerite - "Granny Smith" suite.

The relationship between the two suites is a controversial issue of considerable importance to understanding metasomatism and chemical evolution of the subcontinental mantle. Cr-poor megacrysts have geochemical and isotopic characteristics of ocean island basalts whereas the Granny-Smith - glimmerite MARID suite display a mixture of compositional features characteristic of, on the one hand, OIB and on the other, old enriched continental mantle. Open system hybridization in megacryst evolution is supported by Os-isotope studies of Cr-poor and Granny Smith megacrysts (Carlson and Bell 1997) which indicate a strong signature of continental lithosphere in the latter that is not apparent in $\mathrm{Sr}$ and $\mathrm{Nd}$ isotope systems (Jones 1987). The complexity of these geochemical features are perhaps best explained by processes involving open-system hybridization between 
materials from these two sources. The relationship between these two megacryst suites thus has the potential to reveal aspects of the nature of this process, which is likely fundamental to continental mantle metasomatism.

Age relationships of Cr-poor megacrysts (Jones 1987) and zircons (Zartman et al., 1998) presumed to derive from the "metasomatic" megacryst suite argue for contemporaneous origins and by implication a likely petrogenetic relationship. Moore et al. (1992) have argued on the basis of ilmenite compositional trends that the "metasomatic" suite at Monastery can be derived from the Cr-poor (MST) suite by fractional crystallization. However, these two trends display a mutual distinctiveness in terms of certain inter element ratios (plots involving $\mathrm{Mg \#}, \mathrm{Cr} \#(=100 \mathrm{Cr} /[\mathrm{Cr}+\mathrm{Al}])$ and $\mathrm{Zr} / \mathrm{Nb}$ of ilmenite), which argues against a simple, closed system evolutionary relationship. The incompatible trace element concentrations of the calcic clinopyroxenes lie on direct extensions (e.g., to higher $\mathrm{Ce}, \mathrm{Zr}, \mathrm{Y}$ etc) of the trends established by MST subcalcic clinopyroxenes when plotted as a function of Ca\#. Such relationships at face value also suggest a petrogenetic connection but the lack of systematic variability as a function of $\mathrm{Mg \#}$ in the calcic suite suggests a role for partition coefficient variations or, alternatively, open system behaviour.

We conclude that the two megacryst suites at Monastery Mine may be linked to a common magmatic event, but if so, their petrological relationships to one another are likely to involve complex open system hybridization processes.

\section{References}

Carlson, R.W. and Bell, D.R. 1997. Re-Os systematics of kimberlite megacryst inclusions: implications for the source of kimberlitic magmas. Extended Abstracts, Goldschmidt Conference, Tucson.

Gurney, J.J., Jakob, R. and Dawson, J.B. 1979. Megacrysts from the Monastery kimberlite pipe, South Africa. In F.R. Boyd and H.O.A. Meyer (eds) The Mantle Sample: Inclusions in kimberlites and other volcanics. American Geophysical Union, Washington DC, 227-243.

Jones, R.A. 1987. Strontium and neodymium isotopic and rare earth element evidence for the genesis of megacrysts in kimberelites of southern Africa. In P.H. Nixon (ed) Mantle Xenoliths. John Wiley, Chichester, 711-724.

Moore, R.O., Griffin, W.L., Gurney, J.J., Ryan, C.G., Cousens, D.R., Sie, S. and Suter, G.F. 1992. Trace element geochemistry of ilmenite megacrysts from the Monastery kimberlite, South Africa. Lithos 29, 1-18.

Zartman, R., Richardson, S.H, Gurney, J.J., Moore, R.O. 1998. U-Th-Pb ages of megacrystic zircons from the Monastery kimberlite, Free State, South Africa. This volume. 